\title{
Article \\ Climate Change Challenges and Community-Led Development Strategies: Do They Fit Together in Fisheries Regions?
}

\author{
Marek Furmankiewicz ${ }^{1, *(\mathbb{D})}$, Richard J. Hewitt ${ }^{2,3,4}$, Andrzej Kapusta ${ }^{5}$ and Iga Solecka $^{1}(\mathbb{D}$ \\ 1 Institute of Spatial Management, Wrocław University of Environmental and Life Sciences, \\ 50-357 Wrocław, Poland; iga.solecka@upwr.edu.pl \\ 2 Transport, Infrastructure and Territory Research Group (t-GIS), Geography Department, \\ Faculty of Geography and History, Complutense University of Madrid, 28040 Madrid, Spain; rhewitt@ucm.es \\ 3 Observatorio para una Cultura del Territorio (OCT), 28012 Madrid, Spain \\ 4 Informational and Computational Sciences Group, The James Hutton Institute, Aberdeen AB15 8QH, UK \\ 5 Department of Ichthyology, Stanisław Sakowicz Inland Fisheries Institute, \\ Hydrobiology and Aquatic Ecology, 10-719 Olsztyn, Poland; a.kapusta@infish.com.pl \\ * Correspondence: marek.furmankiewicz@upwr.edu.pl
}

Citation: Furmankiewicz, M.; Hewitt, R.J.; Kapusta, A.; Solecka, I Climate Change Challenges and Community-Led Development Strategies: Do They Fit Together in Fisheries Regions? Energies 2021, 14, 6614. https://doi.org/10.3390/ en14206614

Academic Editor: Dalia Štreimikienè

Received: 15 September 2021

Accepted: 5 October 2021

Published: 13 October 2021

Publisher's Note: MDPI stays neutral with regard to jurisdictional claims in published maps and institutional affiliations.

Copyright: (c) 2021 by the authors. Licensee MDPI, Basel, Switzerland. This article is an open access article distributed under the terms and conditions of the Creative Commons Attribution (CC BY) license (https:// creativecommons.org/licenses/by/ $4.0 /)$.

\begin{abstract}
Coastal and terrestrial fisheries communities in Europe, often economically marginalised, are likely to face severe impacts as climate change becomes more acute. Although progress on climate mitigation and adaptation from national governments remains slow, local development actions can also address these impacts from the bottom up. In this paper we analyse the Fisheries and Sea Operational Programme 2014-2020 and 36 Local Development Strategies prepared within the framework of this programme for the case of Poland. The strategies, which were prepared by cross-sectoral, area-based partnerships known as Fisheries Local Action Groups, are analysed using a content analysis approach. The aim was to assess the degree to which local stakeholders sought to address the climate challenge. We found that the mitigation of climate impacts and the development of renewable energy did not feature prominently in the analysed documents, suggesting that both central policymakers and local stakeholders in Polish fisheries regions had a low level of awareness about the climate problem and their potentially important role in addressing it. Transformation to a post-carbon society undoubtedly requires additional, targeted support and extensive educational activities at the local level, in Poland and elsewhere.
\end{abstract}

Keywords: neo-endogenous development; Community-Led Local Development; fisheries regions; Fisheries Local Action Groups; climate change mitigation and adaptation; renewable energy; Europeanisation of climate policy; Poland

\section{Introduction}

Coastal and terrestrial regions, which derive a significant share of their income from fisheries and aquaculture, have frequently struggled as a result of the diminishing importance of the fisheries sector to national economies (e.g., [1]), something that is a particular problem in Europe [2]. As a result, they are often considered to be marginalised areas, receiving additional support from public funds [3-5]. Currently, the rapid and accelerating changes in the climate caused by greenhouse gas emissions [6] pose an additional threat to the resources and livelihood of these regions [7]. In coastal areas, sea level rise and land lost as a consequence is expected to require costly investments in new coastal infrastructure and resettlement of populations away from affected areas. In land areas of Europe, climate changes (CC) may involve the loss or decline of natural and artificial water sources, the intensification of sudden meteorological phenomena (e.g., floods after periods of drought), changes in the species composition of fish, their predators and pathogens, inter alia [8]. As a result, fishing regions may be more vulnerable to $\mathrm{CC}$ than inland urban areas that do not rely on farming or fishing activities [9]. 
The Community-Led Local Development (CLLD) approach, which supports the cooperation of local stakeholders in the management of local resources in the European Union (EU), is currently an important tool for the participatory development of geographical functional regions [10], as well as those areas where fishing is of high importance [11,12]. In this case, support from the European Maritime and Fisheries Fund (EMFF) can be obtained by cross-sectoral partnerships, called Fisheries Local Action Groups (FLAGs), in which local stakeholders representing businesses (including fisheries), the public sector, and civil society cooperate in planning social and economic development and in implementation of local activities $[13,14]$. The strong emphasis given to local cooperation through these kinds of cross-sector partnerships is due to the emergence and increasing popularity of concepts of participatory, neo-endogenous, place-based, and integrated development in Europe [15-17], in which central programs support the bottom-up activities of the local stakeholders and inhabitants of specific regions, e.g., via FLAGs $[17,18]$. This gives them a high level of independence in defining development goals and taking actions based on local needs $[15,19]$. This support policy can also be linked to the popularity of the work of Elinor Ostrom, who stated that cooperation of local stakeholders in the management of limited resources leads to their more sustainable use while maintaining long-term benefits [20].

The literature on various social and political aspects of Local Action Groups (LAGs) in rural areas is extremely rich $[12,21,22]$. A much smaller number of studies systematically assess the choices and priorities of residents in planning local development $[23,24]$ or their relationship to supra-local goals, e.g., pan-European efforts to smart, sustainable, and inclusive growth with significant emphasis on renewable energy (RE) and the lowcarbon economy $[25,26]$. In contrast, examination of the literature reveals virtually no analyses of the extent to which local stakeholders in FLAGs account for goals related to adaptation and mitigation of CC, including the development of RE. Previous studies on this subject are limited to integrated rural partnerships (Local Action Groups financed from European Agricultural Fund for Rural Development) [27-29] or general studies on neo-endogenous rural development in which some CC mitigation and environmental issues are described $[17,30]$. In this article we aim to address this important research gap.

Adaptation and mitigation of the impacts of CC, including RE development, have been important EU policy goals since the 1990s [31-33], see, e.g., the "Europe 2020" strategy, inter alia [34,35]. In this long-term supportive supra-national policy context, in which the specific actions to be implemented are decided to a great extent by local stakeholders, we would expect the bottom-up development strategies of FLAGs to reflect to some extent the real interests of local stakeholders. In this sense, the degree to which climate and sustainability issues appear in planned actions described in local development strategy documents is a useful indicator of local stakeholders' interest in and awareness of these issues, and the extent to which they consider them relevant to their own communities.

The aim of this study is to determine to what extent policymakers and local stakeholders in Poland, in fishing or aquaculture regions in receipt of local development funding through the CLLD approach, have accounted for climate mitigation and adaptation activities like greenhouse gas emissions reduction and RE development. The sources for our investigation are the Fisheries and Sea Operational Programme (FSOP) 2014-2020 (analysed in Section 4.1) and FLAGs development strategies prepared by local stakeholders for the EU programming period 2014-2020 (which usually meant planning activities until around 2022; analysed in Section 4.2).

The structure of the article is as follows: In the Section 2, we present the general characteristics of fisheries regions in Poland and the possible impact of CC on the characteristics of their economy (Inland regions-Section 2.1; Marine regions-Section 2.2). In Section 2.3 we briefly describe the kinds of CC mitigation and adaptation actions that could be implemented at local level in the fisheries regions analysed. Subsequently, we present the research methodology we used to analyse the FLAG strategy documents (Section 3). Following a detailed description of the results of our analysis (Section 4), we discuss the possible reasons for the relatively low interest in the climate problem among local com- 
munities and compare the results of our research with studies on rural and fisheries Local Action Groups in Poland and in other European countries (Section 5). These considerations lead to final concluding remarks and recommendations for future development policy and scientific research (Section 6).

\section{Fishing Regions in Poland under Pressure from Climate Change-A Brief Introduction to the Topic}

\subsection{Inland Fishing Regions}

Inland waters in Poland cover about $6000 \mathrm{~km}^{2}$, of which lakes occupy $2813 \mathrm{~km}^{2}$ [36], and ponds $650 \mathrm{~km}^{2}$ [37]. Most of the inland waters belong to the Baltic Sea catchment area (99.7\% of the country's area), drained mainly by the Vistula (54\%) and Odra (33.9\%) rivers. The natural fishing lakes are located mainly in the north of the country, in the lake district belt [38]. For the most part, these are shallow (maximum depth below $10 \mathrm{~m}$ ) and small (area below $50 \mathrm{ha}$ ) reservoirs [39]. Artificial ponds are scattered throughout the country's rural areas.

Fishing, both commercial and recreational, is carried out in lakes with a total area of almost $2700 \mathrm{~km}^{2}$. The average professional catches of fish in lakes in 2009-2018 were about 2000 metric tonnes per year [40]. For many years, commercial fisheries have been dominated by: bream (Abramisbram), northern pike (Esoxlucius), vendace (Coregonusalbula), and roach (Rutilus rutilus). Freshwater aquaculture mainly relies on the breeding of carp (Cyprinus carpio, average annual production 18,000 tonnes) and rainbow trout (Oncorhynchus mykiss, average annual production of 16,000 tonnes). Carp ponds are found mainly in the south of Poland. Usually these are farms with an area of up to 50 ha. In turn, the flow-through ponds breeding mainly rainbow trout are located in the north of the country, in the basins of rivers flowing into the Baltic Sea [41,42].

Recreational fishing also has a long and rich tradition, being considered an important form of recreation and often associated with local social activities [43]. The number of people involved in recreational fishing in Poland is estimated at 1.5 million [44,45]. Fishingrelated tourism and leisure are often supported in fishing regions [46], including those covered by FLAGs activities [11,47].

Fishing regions are exposed to adverse climatic changes that can affect the frequency and intensity of extreme events and hydrological conditions. Inland freshwater ecosystems are particularly vulnerable to the effects of CC as warming modifies the habitat conditions of fish significantly [48] - it affects fish physiology and behavior, and alters their growth, reproductive performance, mortality, and distribution [49]. It is estimated that around 30\% of European freshwater fish species are vulnerable to $\mathrm{CC}$, which can affect their economic use [50].

Although an increase in water temperature creates more favourable growth conditions for thermophilic fish species, such as carp, it increases the number of pathogens. An increase in disease cases related to higher water temperature in rivers has been recorded in Poland and Europe, both in salmonids [51,52] and in thermophilic species [53].

Water scarcity, lowering the water level in rivers and water reservoirs, is an increasing problem related to CC in Poland [54,55]. Drought, especially in summer, leads to water deficits in ponds and rivers and to deterioration of water quality [46,56]. It limits the production capacity of many pond farms [37].

Another threat indirectly related to $\mathrm{CC}$ is the pressure of fish predators on livestock facilities, for instance the cormorant (Phalacrocorax carbo), which causes numerous conflicts between nature conservation and fish farming $[57,58]$. Climate warming allows migrating cormorants to stay in areas they previously left due to freezing of both stagnant waters and rivers $[59,60]$. The extended feeding time of cormorants increases the financial losses of fish breeders, which is also noted in the local studies prepared by analysed Polish FLAGs [61].

In addition, the effects of CC will interact with other anthropogenic impacts such as air and water pollution, land-use change, habitat fragmentation and destruction, and the introduction of alien species $[8,62,63]$. 


\subsection{Marine Fishing Regions}

According to Statistics Poland, the internal sea area of Poland was $2041 \mathrm{~km}^{2}$, and the territorial sea area was $8783 \mathrm{~km}^{2}$ in 2020 [64]. The main species, caught in the Polish economic zone in the Baltic Sea are: European sprat (Sprattus sprattus), Atlantic cod (Gadusmorhua), and Atlantic herring (Clupea harengus). The main problems of sea fishing in Poland do not result directly from CC, as they mainly concern the fragmentation of fishing companies, the depletion of fishing vessels, pollution of the Baltic waters and its eutrophication, and the reduction of some fish populations as a result of overfishing $[65,66]$. Increased temperature, combined with pollution, causes more frequent cyanobacterial blooms in coastal zones, which have a negative effect on fish [67] and limit the development of tourism due to the need to periodically close seaside bathing areas. Higher water temperatures may lead to changes in the structure of species composition of marine plants and animals. At the local level of coastal municipalities, sea level rise may result in very high costs of adapting port and settlement infrastructure [68]. The intensity of storms leading to increased coastal erosion is also expected to rise [69]. In the case of coastal lakes, sea level rise could connect them to the sea, which would change the composition of fish communities and the structure of the fisheries. Struggling with the problems of the Baltic Sea requires close international cooperation between the Baltic states [70]. In the marine regions discussed in this study, inland fishing is also present, as noted in Section 2.1.

\subsection{Possible Actions for Adaptation and Mitigation of Climate Change in Fishing Regions in Poland}

Global CC is disrupting the functioning of aquatic ecosystems and the fisheries sector that depends on them. However, there are possible adaptive and preventive measures that can be taken. Several of the preventive actions that can be implemented by local communities in fishing regions are, among others $[8,56,71]$ :

- Reducing greenhouse gas emissions through increasing the energy efficiency of production in fisheries, aquaculture, agriculture, transport, etc.;

- Using RE and heat pumps for heating and cooling all kinds of buildings;

- Production of RE for their own consumption and sale of surplus;

- Protection or restoration of natural green areas (i.e., forests, peatlands, and wetlands) absorbing carbon dioxide.

The possible adaptation measures include, among others:

- Local actions to increase water retention (use of home rainwater reservoirs, land development limiting the rapid runoff of rainwater and facilitating their infiltration);

- Adaptation of the species composition of farmed fish to changed climatic conditions;

- Securing farms against increased pressure from natural predators (e.g., cormorants);

- Construction with increased resistance to violent atmospheric phenomena (air trauma, hurricanes);

- Securing seashores against erosion;

- Adaptation of coastal infrastructure to forecasted higher sea level;

- Limiting development in low-lying areas at risk of flooding (including coastal depressions) through appropriate spatial planning provisions;

- Promoting multifunctional development (not limited only to fishing and aquaculture) to increase the economic resilience of regions.

Given the often highly local nature of the impacts of specific threats, there is excellent potential for mitigation and adaptation activities to be planned and implemented from the bottom up [72]. Local scale actions, if sufficiently widespread, can play a major role both in the transition to a post-carbon society (mitigation) as well as in preparing for changes that cannot be avoided (adaptation). Their impact can be both direct, through execution of necessary measures, and indirect, through a "runaway train" of increasing societal awareness and "social tipping" in which the transition to a post-carbon society becomes the vision and roadmap of the majority $[71,73,74]$. In the further part of the article, we 
analyse whether FLAGs development strategies include the above-noted goals and tasks related to CC mitigation and adaptation, with particular emphasis on the development of local RE sources.

\section{Materials and Methods}

\subsection{The Basic Characteristics of the Subject of the Study}

In the article we analyse the Fisheries and Sea Operational Programme 2014-2020 (FSOP) document (Section 4.1), which determines investment and actions financed by EMFF funds in fisheries regions [75], and 36 Local Development Strategies (LDS) implemented by FLAGs and financed by these funds (Section 4.2).

The majority of FLAGs (24 out of 36) received funding to implement their strategies exclusively from the EMFF within the framework of the FSOP; 11 gained additional funds from EAFRD (European Agricultural Fund for Rural Development), and one FLAG gained additional funds from EAFRD, ESF (European Social Fund), and ERDF (European Regional Development Fund). The area of operation of the FLAGs under study and their main sources of funding are presented in Figure 1. The FLAG areas have not been determined in a methodical manner (e.g., by planners or researchers) but results from the voluntary cooperation of local governments and local communities. Ten FLAGs cover both marine (including sea lagoons) and inland fishing areas, and 26 only inland ones.

Each of the 36 FLAGs analysed comprised between 50 and 300 partners representing businesses (small enterprises, cooperatives, fishers, farmers), the public sector (communes, municipal units), and civil society (third sector organisations and private individuals). The business sector comprised between $4 \%$ to $84 \%$ of individual FLAGs, an average of $40 \%$ (Figure 2). All organisational partners had the opportunity to influence the preparation of their Local Development Strategy; these can therefore be seen as a reflection of the needs and plans of local stakeholders. At a general meeting, FLAG members approved the prepared strategies by voting. Local stakeholders could engage both in strategy building and implementation of local actions or investments by submitting their application to the FLAGs project selection committee.

The detailed administrative regulations for the operation of Local Action Groups have been widely discussed in the literature [12,76] and we will not describe them again in this article. The full rules in force have been written in the UE and national documents [77,78]. The FLAGs strategies analysed have a similar structure and content, as they were prepared for a nationwide competition in which basic recommendations regarding the information provided and the creation of these documents were announced [78]. The current strategy documents were downloaded from the official FLAG websites at the beginning of 2020. These strategies were created by local stakeholders most often in 2014-2015. They usually include goals and action plans for the period 2016-2022 in accordance with the principle that EU-funded projects must be completed and accounted for within two years after the end of a given programming period (in this case it is the period 2014-2020), however this deadline was extended due to the COVID-19 pandemic. Corrections introduced in subsequent years in the documents examined usually concern the amount of funds allocated to individual activities, whereas the main and specific objectives were usually not changed. According to the principles of EU support programmes, the local strategies should be consistent with overarching documents-e.g., national Operational Programmes [17] and the "Europe 2020" strategy [26]. 


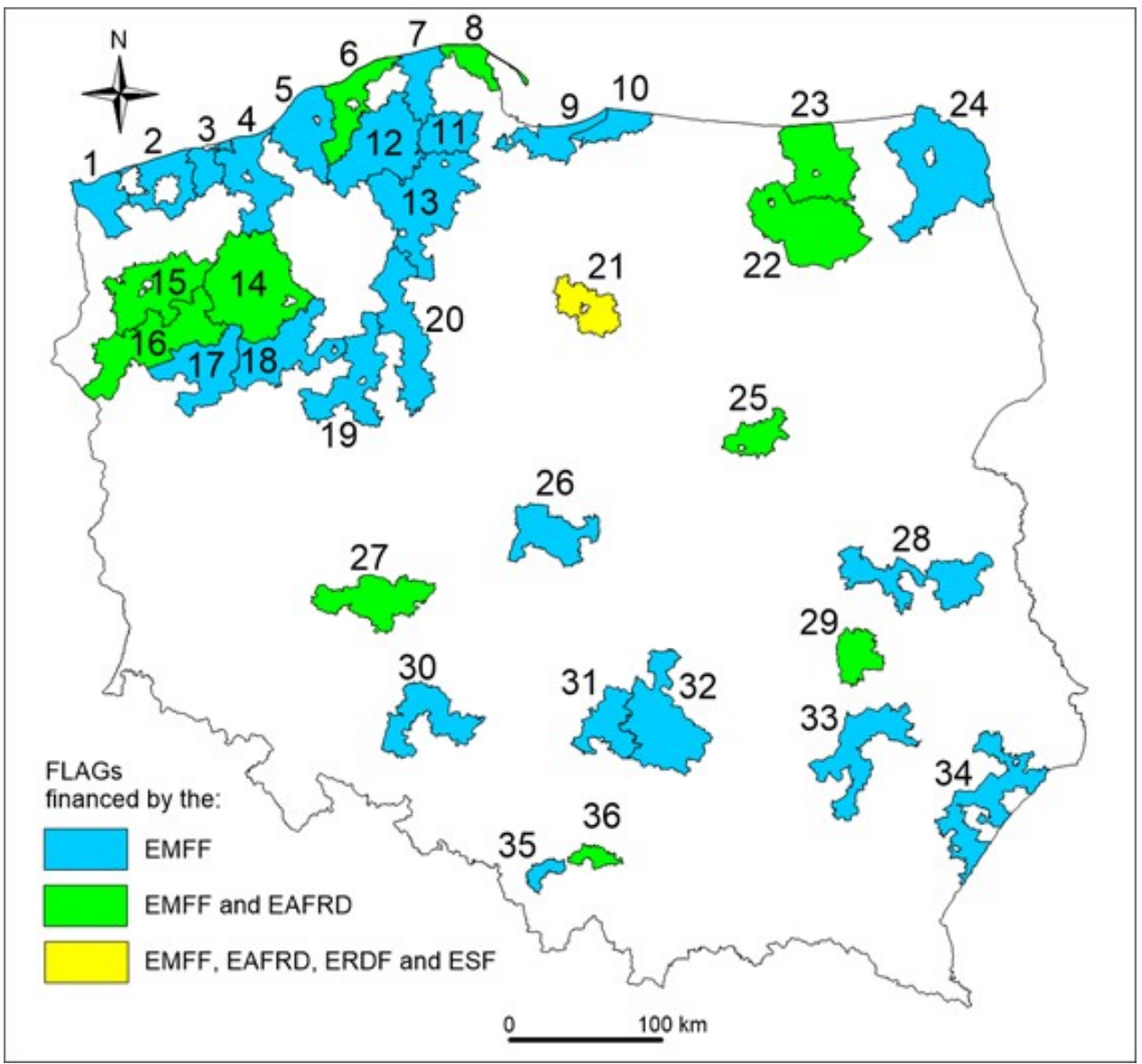

Figure 1. Fisheries Local Action Groups (FLAGs) and their sources of financing in Poland. Acronyms: EMFF-European Maritime and Fisheries Fund; EAFRD—European Agricultural Fund for Rural Development; ERDF—European Regional Development Fund; ESF-European Social Fund. FLAGs names (original in Polish, 'LGD' means LAG): 1. Lokalna Grupa Rybacka "Zalew Szczeciński"; 2. Stowarzyszenie Rybacka LGD Pomorza Zachodniego; 3. Stowarzyszenie Rybacka LGD "Morze i Parsęta”; 4. Mieleńska Lokalna Grupa Rybacka; 5. Darłowska Lokalna Grupa Rybacka w Dorzeczu Wieprzy, Grabowej i Unieści; 6. Słowińska Grupa Rybacka; 7. Stowarzyszenie LGD Dorzecze Łeby; 8. Stowarzyszenie Północnokaszubska Lokalna Grupa Rybacka; 9. Stowarzyszenie Lokalna Grupa Rybacka “Rybacka Brać Mierzei“; 10. Stowarzyszenie Lokalna Grupa Rybacka "Zalew Wiślany"; 11. Lokalna Grupa Rybacka Kaszuby; 12. Rybacka LGD "Pojezierze Bytowskie"; 13. Stowarzyszenie Wdzydzko-Charzykowska Lokalna Grupa Rybacka "Morenka"; 14. Stowarzyszenie LGD "Partnerstwo Drawy z Liderem Wałeckim"; 15. Stowarzyszenie "WIR"—Wiejska Inicjatywa Rozwoju; 16. Stowarzyszenie "Lider Pojezierza”; 17. Rybacka LGD “Pojezierze Dobiegniewskie”; 18. Nadnotecka Grupa Rybacka; 19. Stowarzyszenie Lokalna Grupa Rybacka "7 Ryb"; 20. Stowarzyszenie Lokalna Grupa Rybacka "Nasza Krajna i Pałuki”; 21. Stowarzyszenie "LGD Pojezierze Brodnickie"; 22. LGD “Mazurskie Morze"; 23. Stowarzyszenie Lokalna Grupa Rybacka "Wielkie Jeziora Mazurskie"; 24. Stowarzyszenie Lokalna Grupa Rybacka "Pojezierze Suwalsko-Augustowskie"; 25. LGD Zalew Zegrzyński; 26. Rybacka LGD "Z Ikra”; 27. Partnerstwo Dla Doliny Baryczy; 28. Lokalna Grupa Rybacka "W Dolinie Tyśmienicy i Wieprza”; 29. LGD “Owocowy Szlak”; 30. Rybacka LGD “Opolszczyzna”; 31. Rybacka LGD “Jurajska Ryba”; 32. Świętokrzyska Rybacka LGD; 33. Stowarzyszenie “Lokalna Grupa Rybacka Puszczy Sandomierskiej”; 34. Rybacka LGD "Roztocze"; 35. Lokalna Grupa Rybacka Bielska Kraina; 36. Stowarzyszenie Dolina Karpia. Source: Own work based on data from Ministry of Agriculture and Rural Development (Warsaw, Poland). 


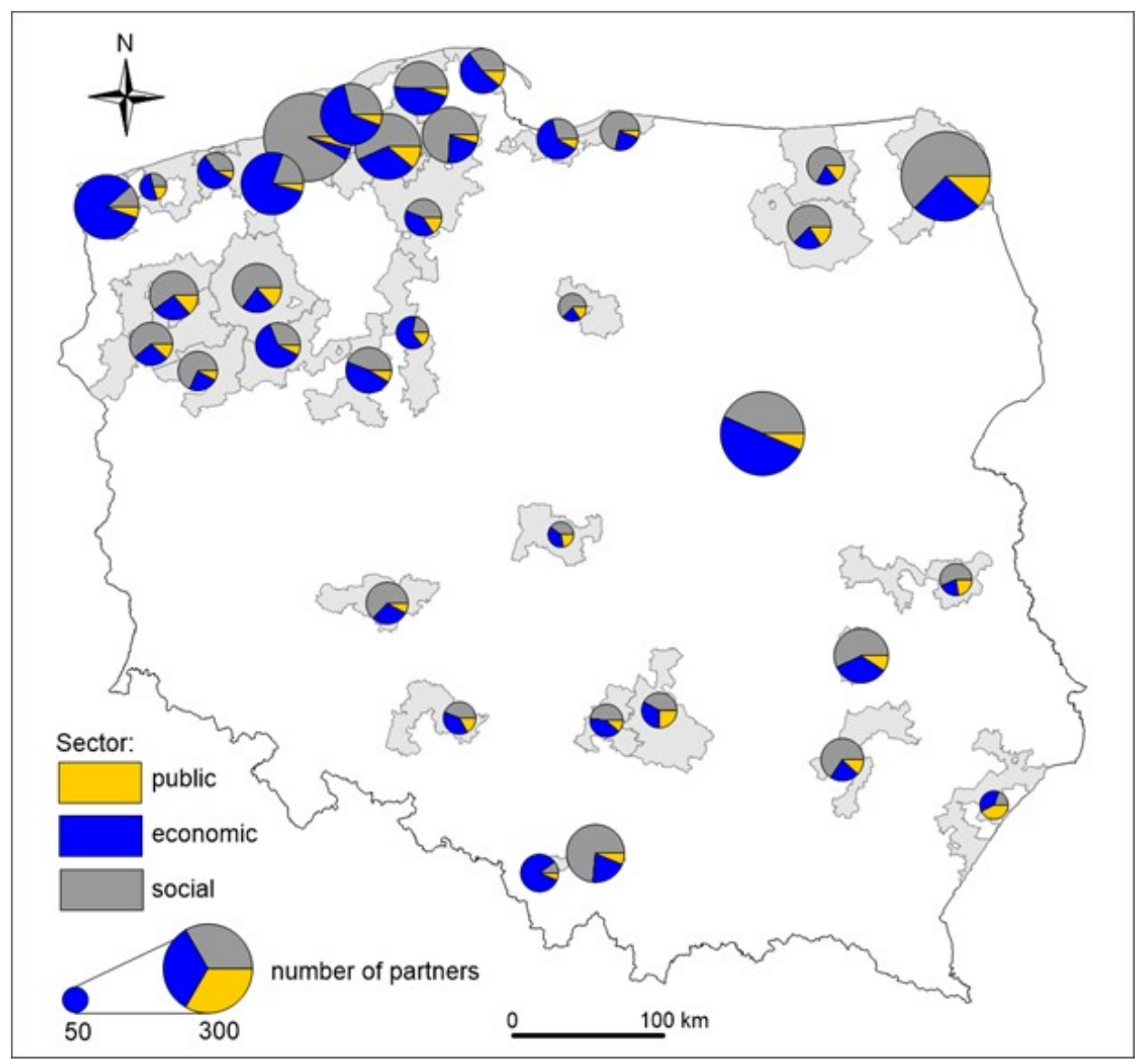

Figure 2. The number of partners and participation of public, economic (business), and social sector stakeholders in Fisheries Local Action Groups in Poland in period of analysed strategies development. Source: Own work based on data from FLAGs strategies and offices.

\subsection{The Method of Analysis}

The main research method used in this work was the analysis of the content of formal documents [79,80], often used in sociological and political science research $[81,82]$. The analysis was divided into three stages:

1. In the first, preliminary stage, the specific policy documents governing the rules under which the FLAGs can obtain financing were reviewed in detail by researchers, since the programme funding structure and rules can be expected to influence the focus of the selected projects;

2. Next, keyword searches related to the research topic (computerized search for phrases "climate change" and "renewable energy; wind; solar; biogas; biofuel; heat pump; thermo-modernisation; energy efficiency") were carried out for the 36 individual strategy documents included in this analysis;

3. Finally, the search results obtained in stage 2 were closely scrutinized by researchers for their meaning (human interpretation).

This approach to the analysis is referred to as "text mining" [83]. Content analysis is often used in the analysis of strategic and planning documents prepared under the supervision of national, regional, and local authorities [84,85], including their policies regarding CC mitigation and adaptation, or the development of RE [86,87]. Specifically, we analysed whether the content of the strategy noted tasks related to (a) CC mitigation and adaptation; (b) RE. Text were analysed by a single researcher to ensure uniform interpretation. We also tried to assess whether the noted goals and activities relate to educational and information campaigns (soft projects), or specific investments in infrastructure and devices 
(hard projects) [88]. The database recorded with codes " 0 " or " 1 " the content relating to the above-noted two issues in the objectives, in the planned activities, and in the performance indicators. This made it possible to obtain uniform quantitative data on the number (and percentage) of strategies that took these issues into account.

Additionally, the number of planned activities (projects) was counted, as well as the planned budget allocated for their implementation (quantitative data); however, these data are incomplete due to imprecise provisions in the strategies. Descriptions and comments recorded in the strategy (qualitative data) were also noted. The collected data on the number and monetary value of planned projects are not suitable for a methodical quantitative analysis, because in many strategies, activities related to counteracting CC or promotion or construction of RE were not clearly separated from larger projects unrelated to this topic. It should be noted that our analysis was limited to the content of the planned activities described in the documents, and not whether the funds were eventually spent on the activities thus described, as the final data on the implementation of tasks will be available only after the completion of activities. Similar methods were used in analysis of rural Local Action Groups strategies financed by EAFRD [28], which enable the comparison of results in the discussion. The analyses were carried out on the full population of FLAGs in Poland, hence we do not use mathematical description methods typical for statistical samples.

\section{Results}

\subsection{The Analysis of the National Fisheries and Sea Operational Programme Financing FLAGs}

In the 2014-2020 programming period, EUR 93 million was allocated to the implementation of FLAG actions in Poland, as part of the Community-Led Local Development approach, from the resources of the European Maritime and Fisheries Fund (EMFF) under the national Fisheries and Sea Operational Programme (FSOP), Priority 4 "Increasing employment and territorial cohesion". The implementation of local development strategies under the FSOP assumed the possibility of co-financing operations related to activities in the field of [75]:

1. Adding value to products, creating jobs, encouraging young people, and promoting innovation at all stages of the product supply chain in the fisheries and aquaculture sector;

2. Support diversification of activities within and outside industrial fisheries, support lifelong learning and job creation in fisheries and aquaculture areas;

3. Support and exploit environmental assets in fisheries and aquaculture areas, including operations to mitigate CC;

4. Promotion of social well-being and cultural heritage in fisheries and aquaculture areas;

5. Give fishing communities a more important role in local development and in managing local fisheries resources and marine activities.

The national FSOP scope of development is related to EMFF aims [17] and could easily adopt the EU Europe 2020 strategy aims related to mitigation and adaptation to CC, with special attention to RE development. Documentation for FSOP indicates that around 21\% of the total programme budget could be used for CC mitigation or adaptation. However, the document notes that, "the basis for mitigating the effects of climate change" is to be "shaping the landscape" and "creating a specific, local microclimate by ponds" ([75] p. 30), which may even suggest a lack of awareness of the CC issue on the part of the document's authors.

The programme indicates that "there is a particular need to diversify the energy sources in aquaculture facilities, both trout and carp, towards RE" ([75] p. 30). However, in the 190page document, support for RE was noted only in one priority (out of the six existing ones), in only one of its seven specific objectives, entitled "Protection and restoration of aquatic biodiversity as well as supporting aquaculture-related ecosystems and promotion of resource-efficient aquaculture", which foresees the implementation of 50 projects in Poland in the field of "productive investments in aquaculture-increasing energy efficiency; RE" ([75] p. 82). For comparison, 510 investment projects not related to RE and 205 for various types of advisory 
services were planned for the same specific objective. Therefore, it can be concluded that $\mathrm{RE}$ and CC mitigation is something of a marginal topic in this document. This low level of attention paid to these aspects in a document defining the financing rules for FLAGs could also have an impact on their projects.

There are no details of individual priorities in the main FSOP document. They were included in several ordinances of the Ministry of Maritime Economy and Inland Navigation. The intermediary institution in the transfer of funds is the state Agency for Development and Modernization of Agriculture. The description of individual priorities and links to the relevant regulations were available on the website dedicated to this programme [75]; however, there is no single document that would describe the objectives and scope of activities in each priority. The individual priorities are covered by separate regulations, which makes them difficult to understand and apply as a whole for local stakeholders interested in submitting applications.

The FSOP is divided into six priorities and technical assistance. The support is targeted at sea fishing, inland fishing, aquaculture, and local communities. FLAGs were able to obtain funds from Priority 4-employment and territorial cohesion in fisheries areas. Priority 1 for sea fishing is divided into 16 measures. Measure 1.15 "Energy efficiency and climate change mitigation" covers only investments in equipment or ships to reduce greenhouse gas emissions and pollutants and to increase the energy efficiency of fishing vessels. Ninety-three applications were submitted in the call for proposals in September 2020, and 54 applications were included in the funding limit (PLN 10,450,000). The aid is aimed at owners of fishing vessels.

Additionally, in Priority 2, which supports aquaculture, sub-measure 2.3.2 concerns "increasing energy efficiency and RE sources". In this measure, assistance is addressed to entities that breed fish. The measure aims to increase energy efficiency based on the use of RE sources. There were three recruitments for this action until the beginning of 2021, for a total amount of PLN 120 million. However, these are not funds distributed via FLAGs, which formulated their own development strategies.

In 2015, 45 associations (existing or planned FLAGs) operating in fisheries regions in Poland applied for FSOP funds to implement their LDS, which eventually was allocated competitively to 36 of them. In the next section we analyse the content of their approved strategies.

\subsection{The Analysis of the FLAGs Development Priorities and Actions}

The most important goal listed in the strategies of the studied FLAGs were issues of entrepreneurship and employment support, which were considered in all the documents analysed (Figure 3). Next in importance was human and social capital development, followed by tourism and recreation (infrastructure and actions). Support for activities in environmental protection and development of ecological infrastructure (including RE) reached the penultimate place, being considered in 16 of the 36 FLAGS (44\%).

The issues of mitigating or adapting to $\mathrm{CC}$ were included in the main or specific objectives of nine of the strategies (25\%, Figure 4$)$; however, it was noted in specific measures (operations) only in six $(17 \%)$ of the analysed documents. This issue was taken into consideration in indicators of operations in 14 (39\%) of the strategies. The logical sum of documents referring to the analysed issue (in targets, actions, or performance indicators) reached only 19 (53\%) of the strategies. Only around $0.6 \%$ of the total LAGs budget was dedicated to these types of measures-almost 3 million PLN (near 750 thousand EUR) out of a total of 519 million PLN (including all national and EU funds). However, these financial data are approximate, since such actions are most commonly listed only as components of other, wider priorities. 


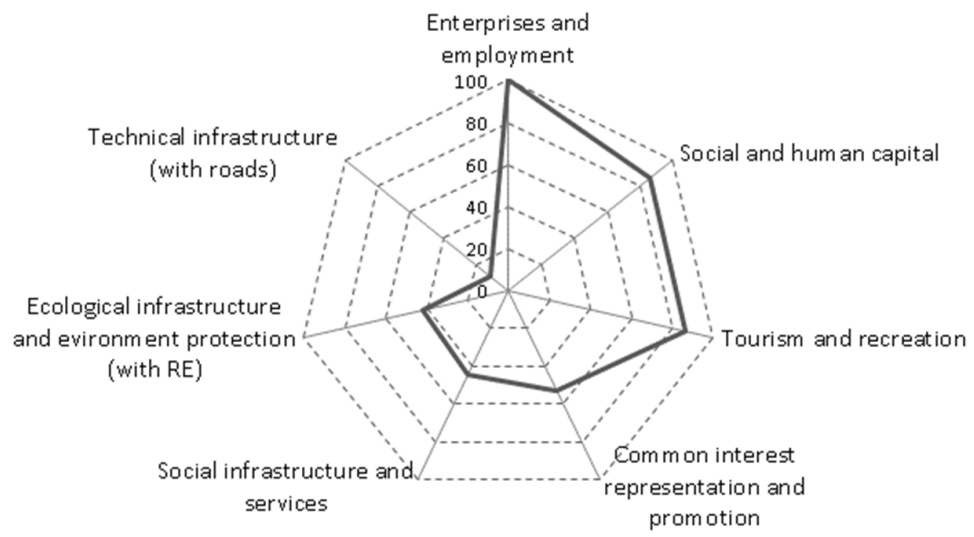

Figure 3. The percentage of FLAG strategies referring to a given issue in the priority aims (EU Programming Period 2014-2020). Source: Authors own work based on data from FLAGs strategies.

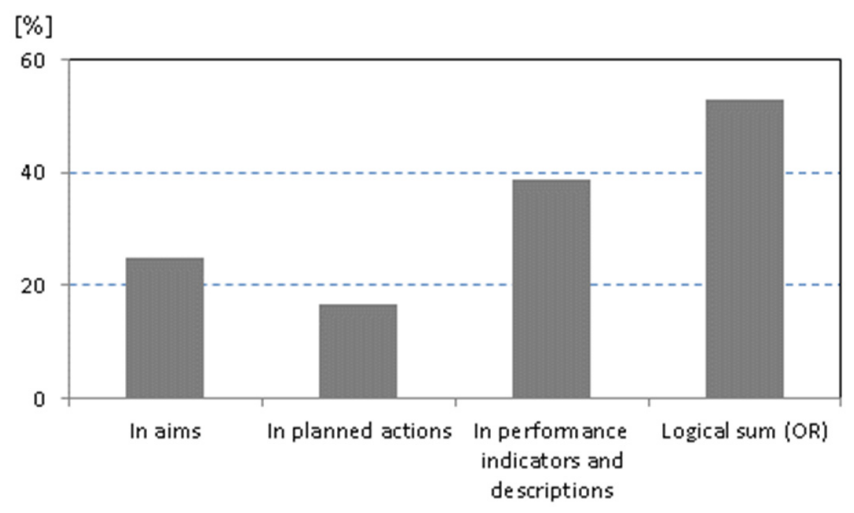

Figure 4. The percentage of FLAGs strategies referring to mitigation or adaptation to climate change in the aims, planned actions, performance indicators, and logical sum of strategies (with "OR" logical operation). Source: Authors own work based on data from FLAGs strategies.

Only nine of the analysed FLAGs (25\%) noted problems of water saving and retention in their strategies. This finding suggests that the issue was not seen as important by local stakeholders involved in strategy development. The priority was economic development related to entrepreneurship and tourism (hence the emphasis on obtaining financial income), as well as social actions (like counteracting poverty and unemployment). Problems related to increasing predator populations (mainly cormorants) were taken into consideration in 17 strategies. Other CC related actions were often noted not as an important goal or recommendation, but only as a voluntary option. For example, in one strategy these issues appear as follows: "[implemented projects] may potentially take into account [possibility only-emphasis added by authors] the use of new technologies with a pro-climate and pro-environmental dimension (emission reduction, water and energy saving, use of RE sources, etc.)" (FLAG-36; quoting entries from documents of individual FLAGs, we use the numbering from Figure 1). Only in some FLAGs were criteria introduced in the assessment to reward local projects that include solutions related to CC impacts (for instance, in FLAG-4 and FLAG-9).

Only two FLAGs (5.6\%) planned training in the field of RE for residents, and six investment in RE (16.7\%), a logical sum of eight LAGs (22\%) taking this issue into consideration (Figure 5). 


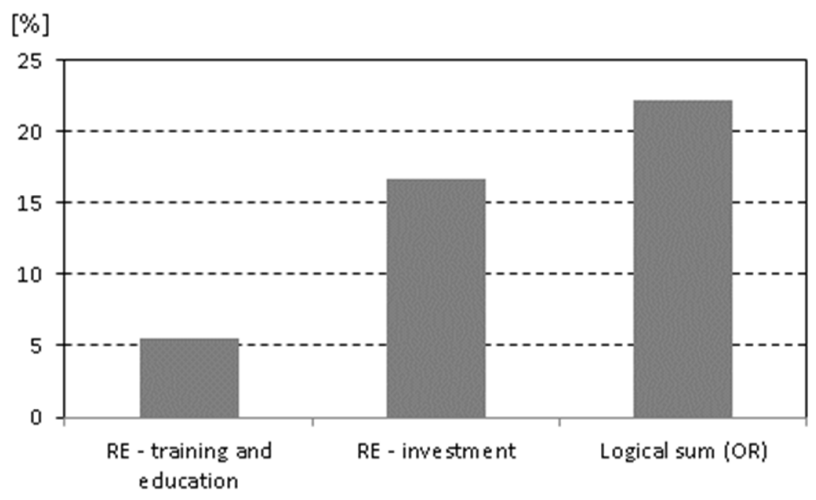

Figure 5. The percentage of FLAGs strategies referring to RE (training and education, and investment) and logical sum of strategies taking RE into consideration in educational actions or investment (with "OR" operation). Source: Authors own work based on data from FLAGs strategies.

Only around 1 million PLN (around 250 thousand EUR) of the total FLAGs budget (519million PLN) was clearly allocated to these types of measures, indicating that the topic was of marginal importance for local residents. For comparison, the issues of the fisheries cultural and historical heritage protection were considered in the main objectives or in description of actions in $83 \%$ of the analysed strategies (logical sum with "OR" logical operation). Hence it seems that traditional aims were much more important for local stakeholders than aspects related to climate impacts or RE. In 12 FLAGs (33\%), ecological awareness of local communities was identified by the authors of the strategy documents as low (usually in the SWOT analysis, in the area's weaknesses). For example, one strategy states that education is needed about "the specificity of the fishing area, the principles of sustainable development based on rational use of resources, environmental protection and counteracting climate change, which the Barycz Valley experiences directly in the form of drought" (FLAG-27).

\section{Discussion}

Our analyses showed that at the time the national FSOP and local strategies for fisheries regions were prepared (around 2014-2015), issues related to CC and RE were not treated by policymakers and local stakeholders as particularly important. For local communities, activities for the development of entrepreneurship, social and human capital, tourism and recreation, were more important. Satisfying typical local needs was poorly related to the supra-local pro-climate goals of the EU. Only six (17\%) of the FLAGs planned investment in RE. The other goals and activities noted in less than half of the analysed documents concerned, inter alia, drought problems and methods of reducing financial losses of fish farmers due to the development of the cormorant population. Local activities focused on providing income and services for residents and business rather than on longterm environmental goals.

Interestingly, in the Polish "LEADER+ Pilot Programme" (2004-2006) measures to develop RE, including energy crops, were present in about $40 \%$ of 40 LAG strategies analysed by Futymski [89]. This topic was in third place in terms of popularity, after the development of tourism and activation of local communities. However, our own results seem to coincide with research on FLAGs operating under the LEADER 4th Axis 2007-2013 in Poland. According to Kurowska et al. [47], coastal FLAGs in Poland focused in turn on: (1) improvement to residents' quality of life, (2) tourism development, (3) protection of the environment, and (4) business activity. Projects related directly to CC and RE were not identified in this analysis. In the Łódź region in Poland, Kalisiak-Mędelska noted only one cooperation project out of three rural LAGs on "changing the mentality of residents, local authorities and entrepreneurs in the use of RE sources", which indicates the low interest of local communities in this subject [90]. Piwowar and Dzikuć [91] argue that the potential for RE development in rural areas in Poland remains mostly unrealised. The study of Pawlewicz 
et al. [14] showed relatively low FLAG engagement around investment in environmental protection, e.g., related to water resources management. In contrast, at the national level, the need to increase water retention as an answer to summer droughts and floods was identified in national policy documents [56,92].

It is difficult to compare the results from Polish FLAGs to similar organizations in other countries. Although the literature on LAGs is extremely rich, as noted in the introduction, it focuses mostly on social and political issues [93-95]. The LAG literature has rarely analysed whether mitigation or adaptation to CC topics appear in rural development strategies and implemented activities. A study by Konečný et al. [96] found that the topic "waste management and usage of renewable sources" appeared in almost 90\% of LAG strategies in the Czech Republic, although no data were provided on how many of these directly related to RE. Taken at face value, these findings would seem to contrast significantly with the results of the present study. In an analysis of a limited number of LAGs from several EU countries, Servillo and De Bruijn [97] noticed that "measures against climate changes" appeared relatively rarely in such organizations. In this comparison, LAGs from Poland showed a relatively high level of interest in this subject, but this concerned only two regions, one of which (Podlaskie Voivodeship), according to Furmankiewicz et al. [29], was characterized by a relatively high interest in RE due to the deliberate policy of the regional authorities. In other regions, the interest in this subject in strategies was significantly lower. Similarly, Camacho et al. [98] when analysing the impact of the LEADER programme on the creation of new jobs in Andalusia, Spain, observed that rural areas lacked "sustained or organized exploitation of renewable energy sources". However, these are probably only regional problems. In comparison with Poland, Spain uses RE to a slightly greater extent (share of RE in gross final energy consumption is $18.4 \%$ compared to 12.6 in Poland in 2019 [99]). In a comparative study of CLLD FLAGs from eight EU countries, the environmental projects covered on average only $10 \%$ of all projects $(7.8 \%$ in Poland). The priorities were diversification (33\%) and socio-cultural (30\%) activities [17]. Additionally, aims related to CC and RE were not present in case study partnerships in the UK and France $[18,100]$. Local stakeholders in Italian FLAGs considered environmental sustainability criteria to be less important than social and economic ones [101]. These studies may suggest that local stakeholders' interest in counteracting and adapting to CC may be relatively low in Europe's fisheries areas generally, not just in Poland. Our own findings, together with the rather sparse comparative literature, seem to suggest a rather low interest by development actors from fisheries regions in climate and clean energy related activities in years 20142015. How, then, can this low level of interest be explained?

In countries which have played a leading role in CC mitigation, the literature points to a range of factors contributing to the successful deployment of RE [102-104], of which the establishment of strong and consistent public financial support mechanisms is probably the most important $[105,106]$. In this sense, Poland's public policy on RE has lagged significantly behind $[107,108]$. Recent forecasts indicate that Poland will not meet the $15 \%$ target share of RE in final consumption originally planned for 2020 [109]. This is mainly due to central government policy, which has so far based the energy sector on domestic lignite and hard coal deposits. The government's single-minded focus on coal is in part driven by nationalist ideology, enshrined in the emotive rhetoric of energy independence, and partly due to the power of the mining lobby (including trade unions), on whom the government relies for political support [110]. It should be emphasized that in Poland almost the entire energy sector (including the dominant coal-fired power plants) is supervised by central authorities through state-owned enterprises (SOEs). In result, in the absence of a political change of direction, these SOEs have no interest in supporting competing, independent producers of distributed RE. These dependencies explain the relatively weak support for RE in the programs of the central authorities in the 2010s, compared with leading EU countries [28,110]. In Poland the entrepreneur could not be a prosumer until 2020, owners of micro-installations producing surplus energy could not make a profit, there were technical and legal problems connecting RE installations to the monopolistic 
state energy system, entrepreneurs are not allowed to sell energy directly to, e.g., nearby consumers [111,112].

According to Proszak-Miasik and Boryło [113], until 2014, the increase in the use of RE in rural areas was small, due to relatively high installation prices and the low level of state funding. Legal and technical limitations in connecting distributed energy sources to the monopolistic state power grid were also of great importance. The national energy system has not been adapted to the development of the RE (very low level of energy storage and low share of gas power plants) [112]. In addition, in 2016, Poland introduced serious restrictions on the development of onshore wind energy and increased taxes paid by wind farms, which was partly related to conflicts common in Poland regarding the location of wind farms in the vicinity of residential buildings [114,115].

The relatively low interest in supporting RE by the central government (visible in the text of the national FSOP) may also be at least partly due to the low interest in RE among local communities-voters. According to Skrzyńska [116] issues related to CC and RE issues were among the "information gaps" of Polish society. According to Wielewska [117] in the opinion of about $70 \%$ of the agricultural advisors she surveyed, the development of dispersed and prosumer energy in rural areas was low, which was justified by the low level of environmental education of the inhabitants.

The inhabitants of rural areas were most often interested in the use of solar panels to heat water [118]. Additionally, farmers most often used biomass and solar energy to produce heat and electricity, and to a lesser extent biogas and wind energy [113]. In Poland, the dominant form of RE in rural areas was the combustion of solid biofuels (wood, straw, etc.- - over $70 \%$ of all primary energy obtained from renewable sources in 2015), which are not emission-free energy sources [119]. About 70\% of farms in rural areas include single-family houses heated with solid fuels-biomass and coal. In suburban areas with well-developed infrastructure houses are also heated with gas. Heat pumps (including recuperators) are relatively rare due to the high investment price, high thermal insulation requirements of the building, and low environmental awareness of rural residents. In the years 2019-2020 interest in the development of solar energy among local communities increased significantly as an answer to national support programmes $[109,120]$, but the development strategies we examined were prepared before this. One of the barriers to the development of community-based RE is undoubtedly the relatively low level of income of rural residents, which is of great importance in capital-intensive investments in RE (especially in the case of thermal modernization of old buildings and the use of heat pumps for their heating).

In Poland, initiatives related to RE in the 2010s seem to be established mainly by the business sector or the local authorities, with little engagement of citizens in collective Community RE projects, at least in comparison with Western UE countries [72]. Social research by Ropuszyńska-Surma and Weglarz in one Polish region (Lower Silesia) showed that people supporting the development of RE were usually those with secondary and higher technical education and people with higher incomes, mostly farmers and private company owners [121]. Although these professional groups were not dominant in traditional rural LAGs (i.e., financed exclusively from EAFRD funds), dominated by social and public sectors [95], they are significantly better represented in FLAGs. This is likely to be due to the recommendations of the central authorities to secure the participation of farmers, fishers, and fishing sector entrepreneurs in this type of LAG. Characteristically, the interest in RE investments (15\% of the strategy) in FLAGs is higher than the average in rural LAGs in Poland (9\%) [28], which is generally consistent with the research by Ropuszyńska-Surma and Weglarz [121]. This supports the idea, that at local level, farmers and private company owners were more interested in the use of RE than organizations and individuals in social and public sectors.

Analyses of LAGs in the EU by other authors also suggest that organizations of this type focus on the development of productive activities (e.g., local products) and tourism, based on cultural heritage and local natural resources [122-124] and on social issues, often 
related to the problem of social exclusion [13,125-127]. A recent survey of LAGs in Spain noted difficulties in implementation of technological innovations like digital governance in many traditional rural areas [128], and this also applies to the use of new technologies (including RE) in ageing rural communities in Poland [72,129]. Traditional communities tend to engage slowly with activities promoted by central policies [130].

The results of our study indicate that CC mitigation or adaptation measures need additional support in fisheries regions represented by FLAGs, as well as in rural areas more generally. Research from other countries leads to similar conclusions. In the analysis of LAGs in Slovakia, the authors stated that more attention should be paid to the issues of RE, which was not an important goal for local communities there [131]. Doitchinova et al. [132] observed that National Rural Networks, which serve to exchange information and promote innovation among national LAGs in Bulgaria, could play a strong role in promoting RE issues. Similarly, based on results from of LAG questionnaires in EU, the European LEADER Association for Rural Development concluded that more attention should be paid to, inter alia, alignment with and adaptation to changing living and working environments in rural areas, including issues of the green economy and CC [133]. These findings suggest that stronger emphasis should be given to the importance of climate mitigation and adaptation measures in European level development programmes. Although the CLLD approach rightly empowers local communities to decide appropriate rural development actions for their area, funding agencies should also be empowered to insist on a stronger focus on climate and energy transition measures where these are conspicuously absent.

\section{Conclusions}

The aim of this work was to determine to what extent policymakers and local communities in Poland, engaged in the implementation of Community-Led Local Development, have considered climate mitigation and adaptation measures (with special attention to RE) in the national FSOP 2014-2020 and in 36 Local Development Strategies financed within the framework of this programme. The results show that analysed issues were not seen as important by local stakeholders. The key points are:

1. Policymakers and local stakeholders associated with fishing and aquaculture in Poland focused on traditional actions like supporting entrepreneurship for increasing profits and employment, tourism development, and social inclusion. The issues identified as CC mitigation and adaptation enjoyed much less interest and related mainly to educational activities.

2. Local actions focused on the current, most visible indirect effects of CC, such as counteracting the effects of drought and cormorant population growth.

3. The possible contribution to measures to combat CC by reducing greenhouse gas emissions (including the development of RE) received hardly any attention at the local level. The sources of CC were treated as distant, external factors over which the local community has no influence.

4. The authors of local strategies identified low environmental awareness of local communities in 12 FLAGs (33\%); however, only two planned training in RE for residents. Being conscious about low environmental awareness is the first step that must be made before education and investment. At the time the strategies were developed the level of consciousness of environmental issues was likely too low to influence the actions in a substantive way.

5. The use of RE as a source of additional savings (or income) was planned to a very low degree. This was partly due to the energy policy of the central authorities and local stakeholders' low interest in RE.

According to our research, the inhabitants of fishing regions notice the most visible changes (heat, drought, species changes) and try to counteract them locally. At the same time, they disregard involvement in global and European efforts for CC mitigation. In local development activities planned from the bottom up by local communities, issues related 
to the transformation to a low-carbon economy are usually treated as secondary to other needs. Hence, our recommendations focus on specific support for the following activities:

1. Global efforts to reduce greenhouse gas emissions should be more closely associated with broad activities to educate the public and change local non-ecological habits (e.g., use of coal stoves for heating, etc.). Through educational activities, local stakeholders need to become more aware of the global effects of many local activities.

2. For local communities to support the development of local RE (with energy storage) and low-emission technologies, they must receive tangible benefits from it. On their own, environmental education programmes tend to bring poor results. Of course, these are necessary to improve social awareness of the climate problem, but there is a need to link environmental education to local benefits in a meaningful way.

3. Greater effort should be invested in activities aimed at increasing the energy and thermal energy efficiency of residential and farm buildings, as well as agricultural and fishery processing. Polish energy policy has so far focused on energy production, and not on limiting energy consumption (which would be unfavourable for state-owned energy producers).

4. Support for the development of dispersed, local RE requires the use of targeted funds intended only for this purpose (ringfenced). Yet aid programs of this kind could easily be used to promote highly profitable strategies that combine climate goals with local needs (e.g., supporting the ideas of a local entrepreneur, farmer, or fisherman, provided that the project also includes elements of increasing energy efficiency, using RE with energy storage, reducing greenhouse gas emissions, etc.).

CC mitigation and adaptation is dominated by a global approach and the formulation of climate policy goals for entire countries [6]. This is, of course, justified by the need to take decisive actions at a large scale, but it is also essential to support mitigation and adaptation activities implemented by local communities from the bottom up [134]. European policymakers have belatedly realised this, as can been seen from the support for community energy in recent EU policy measures [135], but much more needs to be done to make a bottom-up transition a reality. It is clear from our analysis that the goals of local stakeholders working together in partnerships in fisheries regions have usually been poorly related to the pan-European climate goals. This indicates the need for greater stimulation of efforts to transform towards the low-carbon economy also at the local level, i.e., through strong support for community RE production and energy savings initiatives at all levels. It is also clear from our study that the tendency to maintain the status quo is not exclusive to incumbent utilities or conservative business elites associated with energy based on the combustion of fossil fuels, who might be expected to have the most to lose from the new order. For various reasons, local level stakeholders are also highly resistant to change [130] and mostly unwilling to address their own role in transforming behaviours known to be harmful to the natural environment.

Finally, it is important to be aware of the limitations of the research presented. Local development strategy documents are secondary materials, the content of which has been influenced by a limited number of people, even if they were consulted at meetings with local communities. Most authors accept a priori that strategy documents of this kind reflect the real needs of local communities, but the real impact of local interest groups is unknown; this is something should be taken into consideration and a possible topic for future work. Content analysis (and thus the qualitative method) is also influenced by the subjective understanding of the content by the authors [79]. It should also be remembered that the analysed strategies were created in 2014-2015, so they represent the historical rather than the current needs of the local stakeholders. Further, the implementation of local strategies in practice may differ from planned activities. There are many reasons why this might happen, e.g., legal and financial constraints, or practical limitations not previously foreseen. Future research might usefully analyse the scope of completed projects, supported by interviews with local stakeholders. In this case, it would be advisable to use a scientific, unified typology of projects, and not to rely only on financial statements, which organise data 
by administrative budget categories. This is especially true in international comparisons, where different national interpretations of project types and difficulty in accessing detailed data are known problems [17].

Author Contributions: Conceptualization, M.F.; methodology, M.F.; software, M.F; validation, M.F.; formal analysis, M.F.; investigation, M.F.; resources, M.F.; data curation, M.F.; writing—original draft preparation, M.F., R.J.H., A.K., and I.S.; writing-review and editing, M.F., R.J.H., A.K., and I.S.; visualization, M.F. and I.S.; supervision, M.F.; project administration, M.F.; funding acquisition, M.F. All authors have read and agreed to the published version of the manuscript.

Funding: This paper was co-financed within the project No. 2019/33/B/HS4/00176 (OPUS 17) by the National Science Centre in Poland and by the Wroclaw University of Environmental and Life Sciences, Leading Research Groups support project, from the subsidy increased for the period 2020-2025 in the amount of $2 \%$ of the subsidy referred to Art. 387 (3) of the Law of 20 July 2018 on Higher Education and Science, obtained in 2019. Richard J. Hewitt gratefully acknowledges support provided by the Spanish Ministry of Science, Innovation, and Universities (TERRYER project, Ref CS02017-84986), and by the European Union under Programme H2020-EU.1.3.2, MSCA-IF-2019 (INTRANCES Project, Ref 886050).

Data Availability Statement: Data available on request from the authors.

Acknowledgments: We would like to thank the Ministry of Agriculture and Rural Development, Warsaw, Poland for providing cartographic and statistical data on FLAGs in Poland.

Conflicts of Interest: The authors declare no conflict of interest. The funders had no role in the design of the study; in the collection, analyses, or interpretation of data; in the writing of the manuscript, or in the decision to publish the results.

\section{References}

1. Hadjimichael, M. Losing Space: The Rise of the Blue Economy and the Marginalisation of Small-Scale Fishers in Cyprus. In Small-Scale Fisheries in Europe: Status, Resilience and Governance; Pascual-Fernández, J.J., Pita, C., Bavinck, M., Eds.; Springer Nature: Cham, Switzerland, 2020; pp. 105-123.

2. Pascual-Fernández, J.; Pita, C.; Bavinck, M. (Eds.) Small-Scale Fisheries in Europe: Status, Resilience and Governance; Springer Nature: Cham, Switzerland, 2020.

3. Carvalho, N.; Rege, S.; Fortuna, M.J.A.; Isidro, E.J; Edwards-Jones, G. Estimating the impacts of eliminating fisheries subsidies on the small island economy of the Azores. Ecol. Econ. 2011, 70, 1822-1830. [CrossRef]

4. Churski, P. Problem areas in Poland in terms of the objectives of the European Union's regional policy. Eur. Plan. Stud. 2005, 13, 45-72. [CrossRef]

5. Bański, J.; Degórski, M.; Komornicki, T.; Śleszyński, T. The delimitation of areas of strategic intervention in Poland: A methodological trial and its results. Morav. Geogr. Rep. 2018, 26, 84-94. [CrossRef]

6. OECD. The Economic Consequences of Climate Change; OECD Publishing: Paris, France, 2015.

7. Peck, M.; Pinnegar, J.K. Chapter 5: Climate Change Impacts, Vulnerabilities and Adaptations: North Atlantic and Atlantic Arctic Marine Fisheries; Food and Agriculture Organization of the United Nation: Rome, Italy, 2018; pp. 87-111.

8. Barange, M.; Bahri, T.; Beveridge, M.C.M.; Cochrane, K.L.; Funge-Smith, S.; Poulain, F. (Eds.) Impacts of Climate Change on Fisheries and Aquaculture: Synthesis of Current Knowledge, Adaptation and Mitigation Options; Food and Agriculture Organization of the United Nation: Rome, Italy, 2018; Volume 627.

9. Kiełkowska, J.; Tokarczyk-Dorociak, K.; Kazak, J.; Szewrański, S.; van Hoof, J. Urban Adaptation to Climate Change Plans and Policies-The Conceptual Framework of a Methodological Approach. J. Ecol. Eng. 2018, 19, 50-62. [CrossRef]

10. Konečný, O. The Leader Approach Across The European Union: One Method of Rural Development, Many Forms of Implementation. Eur. Countrys. 2019, 11, 1-16. [CrossRef]

11. Bartłomiejski, R. Fisheries Local Action Groups: A New Theme for Researching Maritime Communities. Rocz. Socjol. Morskiej. Annu. Mar. Sociol. 2011, 20, 46-55.

12. Zajda, K.; Kołomycew, A.; Sykała, Ł.; Janas, K. Leader and Community-Led Development Approach. Polish Experiences; Wydawnictwo Uniwersytetu Łódzkiego: Łódź, Poland, 2017.

13. Piñeiro-Antelo, M.Á.; Lois-González, R.C. The role of European fisheries funds for innovation and regional development in Galicia (Spain). Eur. Plan. Stud. 2019, 12, 2394-2410. [CrossRef]

14. Pawlewicz, K.; Szamrowski, P.; Pawlewicz, A. Fisheries local action groups as a driving force for the implementation of environmental investments in Poland. In Proceedings of the Geoconference on Ecology, Economics, Education and Legislation, SGEM 2014, Albena, Bulgaria, 17-26 June 2014; Volume III, pp. 167-174. 
15. Bosworth, G.; Annibal, I.; Carroll, T.; Price, L.; Sellick, J.; Shepherd, J. Empowering Local Action through Neo-Endogenous Development; The Case of LEADER in England. Sociol. Rural. 2016, 56, 427-449. [CrossRef]

16. Furmankiewicz, M.; Campbell, A. From Single-Use Community Facilities Support to Integrated Sustainable Development: The Aims of Inter-Municipal Cooperation in Poland, 1990-2018. Sustainability 2019, 11, 5890. [CrossRef]

17. Miret-Pastor, L.; Svels, K.; Freeman, R. Towards territorial development in fisheries areas: A typology of projects funded by Fisheries Local Action Groups. Mar. Policy 2020, 119, 104111. [CrossRef]

18. Phillipson, J.; Symes, D. Finding a Middle Way to Develop Europe's Fisheries Dependent Areas: The Role of Fisheries Local Action Groups. Sociol. Rural. 2015, 55, 343-359. [CrossRef]

19. Barca, F.; McCann, P.; Rodríguez-Pose, A. The case for regional development intervention: Place-based versus place-neutral approaches. J. Reg. Sci. 2012, 52, 134-152. [CrossRef]

20. Ostrom, E. Governing the Commons. The Evolutions of Institutions for Collective Action; Cambridge University Press: Cambridge, UK, 1990.

21. Shishkova, M. Implementation of Community-Led Local Development strategies—Evidence from southern Bulgaria. Sci. Pap. -Ser. Manag. Econ. Eng. Agric. Rural Dev. 2020, 20, 537-542.

22. Cejudo, E.; Navarro, F. Neoendogenous Development in European Rural Areas. Results and Lessons; Springer Nature: Cham, Switzerland, 2020.

23. Kisiel, R.; Gierwiatowska, M. Functioning of the Polish LAG in the context of the LEADER initiative. Acta Sci. Polonorum. Oeconomia 2013, 12, 39-50.

24. Belliggiano, A.; Cejudo, E.; De Ruberti, S. The Role of Agriculture in Rural Development in Spain and Italy Within the Framework of the LEADER 2007-2013 Programming Period. In Neoendogenous Development in European Rural Areas. Results and Lessons; Cejudo, E., Navarro, F., Eds.; Springer Nature: Cham, Switzerland, 2020; pp. 149-180.

25. Martí-Ballester, C.-P. Do European renewable energy mutual funds foster the transition to a low-carbon economy? Renew. Energy 2019, 143, 1299-1309. [CrossRef]

26. Furmankiewicz, M.; Janc, K.; Kaczmarek, I.; Solecka, I. Are Rural Stakeholder Needs Compliant with the Targets of the Europe 2020 Strategy? Text Mining Analysis of Local Action Group Strategies from Two Polish Regions. In Hradec Economic Days, Proceedings of the International Scientific Conference Hradec Economic Days 2021, Hradec Králové, Czech Republic, 25-26 March 2021; Mačí, J., Marešová, P., Firlej, K., Soukal, I., Eds.; University of Hradec Králové: Hradec Králové, Czech Republic, 2021; pp. 195-205.

27. Furmankiewicz, M.; Bochenkiewicz, M. Renewable Energy and Community-Led Local Development in Poland: Do Rural Communities Take Measures to Combat Climate Change? In Sustainable Development Goals 2030: Challenges for South and Eastern European Countries and the Black Sea Region, Proceedings of the 15th International Conference of ASECU, Sofia, Bulgaria, 26-27 September 2019; Goev, V., Zarotiadis, G., Eds.; UNWE Publishing Complex: Sofia, Bulgaria, 2019; pp. 212-221.

28. Furmankiewicz, M.; Hewitt, R.J.; Kazak, J.K. Can rural stakeholders drive the low-carbon transition? Analysis of climate-related activities planned in local development strategies in Poland. Renew. Sustain. Energy Rev. 2021, 150, 111419. [CrossRef]

29. Furmankiewicz, M.; Hewitt, R.J.; Janc, K.; Kazak, J.K. Europeanisation of energy policy and area-based partnerships: Regional diversity of interest in renewable energy sources in local development strategies in Poland. IOP Conf. Ser. Earth Environ. Sci. 2020, 609, 012033. [CrossRef]

30. Dax, T. Neoendogenous Rural Development in Mountain Areas. In Neoendogenous Development in European Rural Areas: Results and Lessons; Cejudo, E., Navarro, F., Eds.; Springer Geography: Cham, Switzerland, 2020; pp. 3-19.

31. Kazak, J.K.; Kamińska, J.A.; Madej, R.; Bochenkiewicz, M. Where Renewable Energy Sources Funds are Invested? Spatial Analysis of Energy Production Potential and Public Support. Energies 2020, 13, 5551. [CrossRef]

32. Amanatidis, G.; Cujkova, J. European Policies on Climate and Energy Towards 2020, 2030 and 2050; Directorate-General for Internal Policies, European Parliament: Brussels, Belgium, 2019.

33. Kluza, K.; Zioło, M.; Bak, I.; Spoz, A. Achieving Environmental Policy Objectives through the Implementation of Sustainable Development Goals. The Case for European Union Countries. Energies 2021, 14, 2129. [CrossRef]

34. European Commission. Europe 2020. A Strategy for Smart, Sustainable and Inclusive Growth, Communication from the Commission 3.3.2010 COM(2010); European Commission: Brussels, Belgium, 2010; Available online: http:/ / eur-lex.europa.eu/LexUriServ / LexUriServ.do? uri=COM:2010:2020:FIN:EN:PDF (accessed on 14 September 2021).

35. Rogge, N. EU countries' progress towards 'Europe 2020 strategy targets'. J. Policy Modeling 2019, 41, 255-272. [CrossRef]

36. Choiński, A. Katalog Jezior Polski; Wydawnictwo Naukowe UAM: Poznań, Poland, 2013.

37. Lirski, A. Uwagi na temat warunków wodnych stawów karpiowych w Polsce. Komun. Ryb. 2020, 3, 1-36.

38. Kapusta, A.; Bogacka-Kapusta, E.; Wołos, A. Fish and Fisheries in the Lakes of Northeastern Poland. In Polish River Basins and Lakes_Part II. Biological Status and Water Management; Korzeniewska, E., Harnisz, M., Eds.; Springer Nature: Cham, Switzerland, 2020; pp. 239-249.

39. Dynowska, I. Obieg wody. In Geografia Polski. Środowisko Przyrodnicze; Starkel, L., Ed.; Wydawnictwo Naukowe PWN: Warszawa, Poland, 1991; pp. 350-387.

40. Wołos, A.; Draszkiewicz-Mioduszewska, H. Gospodarka rybacka w śródlądowych wodach płynących w 2018 roku. Cz. 1. Uprawnieni do rybactwa, obwody rybackie, połowy gospodarcze, zatrudnienie i połowy amatorskie. Komun. Ryb. 2020, 1, 13-22. 
41. Zakes, Z. Poland. National Aquaculture Sector Overview Fact Sheet. In National Aquaculture Sector Overview; FAO Fisheries Division, Ed.; Food and Agriculture Organization of the United Nations: Rome, Italy, 2005; Available online: http: / www.fao. org/fishery/countrysector/naso_poland/en (accessed on 14 September 2021).

42. Lirski, A.; Myszkowski, L. Polska akwakultura w 2017 roku na podstawie analizy kwestionariuszy RRW-22. Część 1. Komun. Ryb. 2018, 6, 14-22.

43. Czarkowski, T.; Kupren, K.; Turkowski, K.; Kucharczyk, D.; Kozłowski, K.; Mamcarz, A. Recreational fisheries and fishing grounds in the context of the tourist attractiveness of lakeland regions. Pol. J. Nat. Sci. 2012, 27, 453-463.

44. Arlinghaus, R.R.; Aas, Ø.; Alós, J.; Arismendi, I.; Bower, S.; Carle, S.; Czarkowski, T.; Freireg, K.M.F.; Hu, J.; Hunt, L.M.; et al. Global Participation in and Public Attitudes Toward Recreational Fishing: International Perspectives and Developments. Rev. Fish. Sci. Aquac. 2020, 29, 58-95. [CrossRef]

45. Czarkowski, T.K.; Wołos, A.; Kapusta, A. Socio-economic portrait of Polish anglers: Implications for recreational fisheries management in freshwater bodies. Aquat. Living Resour. 2021, 34, 19. [CrossRef]

46. Tokarczyk-Dorociak, K.; Drabiński, A.; Szewrański, S.; Mazurek, S.; Kraśniewska, W. Conditions of Fish Farming in Natura 2000 Areas, Based on the Example of the Catchment of Barycz. J. Ecol. Eng. 2016, 17, 185-192. [CrossRef]

47. Kurowska, K.; Kryszk, H.; Gwiaździńska-Goraj, M. Sustainable development of coastal areas-Polish experience following accession to the European Union based on the example of Fisheries Local Action Groups (FLAGs) during 2007-2013. Acta Adriat. Int. J. Mar. Sci. 2014, 55, 163-178.

48. Comte, L.; Buisson, L.; Daufresne, M.; Grenouillet, G. Climate-induced changes in the distribution of freshwater fish: Observed and predicted trends. Freshw. Biol. 2012, 58, 625-639. [CrossRef]

49. Lynch, A.J.; Myers, B.; Chu, C.; Eby, L.A.; Falke, J.A.; Kovach, R.P.; Krabbenhoft, T.J.; Kwak, T.J.; Lyons, J.; Paukert, C.P.; et al. Climate change effects on North American inland fish populations and assemblages. Fisheries 2016, 41, 346-361. [CrossRef]

50. Jarić, I.; Lennox, R.J.; Kalinkat, G.; Cvijanović, G.; Radinger, J. Susceptibility of European freshwater fish to climate change: Species profiling based on life-history environmental characteristics. Glob. Chang. Biol. 2019, 25, 448-458. [CrossRef]

51. Grawiński, E. Mało znane choroby ryb łososiowatych występujące na obszarze północnej Polski. Życie Weterynaryjne 2010, 85, 522-528.

52. Borgwardt, F.; Unfer, G.; Auer, S.; Waldner, K.; El-Matbouli, M.; Bechter, T. Direct and Indirect Climate Change Impacts on Brown Trout in Central Europe: How Thermal Regimes Reinforce Physiological Stress and Support the Emergence of Diseases. Front. Environ. Sci. 2020, 8, 59. [CrossRef]

53. Panicz, R.; Eljasik, P.; Śmietana, N.; Sadowski, J.; Biernaczyk, M. New invertebrate species as potential CyHV-3 reservoirs: A case study of common carp mortalities in hyperthermal conditions. J. Fish Dis. 2020, 43, 821-824. [CrossRef]

54. Kubiak-Wójcicka, K.; Machula, S. Influence of Climate Changes on the State of Water Resources in Poland and Their Usage. Geosciences 2020, 10, 312. [CrossRef]

55. Czarkowski, T.K. Rybactwo, agroturystyka i konsumpcja ryb oraz ich wzajemne powiązania w kontekście zrównoważonego rozwoju pojezierzy. In Zrównoważone korzystanie z zasobów rybackich na tle ich stanu w 2014 roku; Mickiewicz, M., Wołos, A., Eds.; Wydawnictwo IRS: Olsztyn, Poland, 2014; pp. 145-157.

56. Łabędzki, L. Actions and measures for mitigation drought and water scarcity in agriculture. J. Water Land Dev. 2016, 29, 3-10. [CrossRef]

57. Marzano, M.; Carss, D.N.; Cheyne, I. Managing European cormorant-fisheries conflicts: Problems, practicalities and policy. Fish. Manag. Ecol. 2013, 20, 401-413. [CrossRef]

58. Traczuk, P.; Chybowski, Ł.; Ulikowski, D. Wpływ kormorana na ichtiofaunę i gospodarkę rybacką. In Działania prośrodowiskowe w racjonalnej gospodarce rybackiej; Wołos, A., Ed.; Wydawnictwo IRS: Olsztyn, Poland, 2018; pp. 119-128.

59. Bobrek, R.; Wilk, T.; Pępkowska-Król, A. Występowanie kormorana Phalacrocorax carbo w polskiej części Karpat w okresie pozalęgowym—Dynamika przelotu i liczebność na zbiornikach wodnych. Ornis Pol. 2018, 59, 89-106.

60. Lyach, R.; Blabolil, P.; Čech, M. Great Cormorants Phalacrocorax carbo feed on larger fish in late winter. Bird Study 2018, 65, 249-256. [CrossRef]

61. Martyniak, A.; Hliwa, P.; Szymańska, U.; Stańczak, K.; Gomułka, P.; Król, J. Próba oszacowania presji kormorana czarnego Phalacrocorax carbo (L. 1758) na ichtiofaunę wód na terenie Stowarzyszenia Lokalna Grupa Rybacka "Opolszczyzna" oraz Stowarzyszenia Lokalna Grupa Rybacka "Żabi Kraj”; Stowarzyszenie Lokalna Grupa Rybacka “Opolszczyzna”, Stowarzyszenie Lokalna Grupa Rybacka "Żabi Kraj": Opole, Poland; Skoczów, Poland, 2014.

62. MacKenzie, B.R.; Gislason, H.; Möllmann, C.; Köster, F.W. Impact of 21st century climate change on the Baltic Sea fish community and fisheries. Glob. Chang. Biol. 2007, 13, 1348-1367. [CrossRef]

63. Thøgersen, T.T.; Hoff, A.; Frost, H.S. Fisheries management responses to climate change in the Baltic Sea. Clim. Risk Manag. 2015, 10, 51-62. [CrossRef]

64. Borek, D.; Głowacka-Smolis, K.; Gustyn, J.; Kozera, A.; Kozłowska, J.; Marikin, M.; Morytz-Balska, E.; Piotrowski, F.; RybakNguyen, E.; Safader, M.; et al. Mały Rocznik Statystyczny Polski (Concise Statistical Yearbook of Poland); Główny Urząd Statystyczny: Warszawa, Poland, 2021.

65. Rakowski, M.; Mytlewski, A.; Psuty, I. Small-Scale Fisheries in Poland. In Small-Scale Fisheries in Europe: Status, Resilience and Governance; Pascual-Fernández, J.J., Pita, C., Bavinck, M., Eds.; Springer International Publishing: Cham, Switzerland, 2020; pp. 503-517. 
66. LaMere, K.; Mäntyniemi, S.; Haapasaari, P. The effects of climate change on Baltic salmon: Framing the problem in collaboration with expert stakeholders. Sci. Total Environ. 2020, 738, 140068. [CrossRef] [PubMed]

67. von Nordheim, L.; Kotterba, P.; Moll, D.; Polte, P. Lethal effect of filamentous algal blooms on Atlantic herring (Clupea harengus) eggs in the Baltic Sea. Aquat. Conserv. Mar. Freshw. Ecosyst. 2020, 30, 1362-1372. [CrossRef]

68. von Storch, H.; Omstedt, A.; Pawlak, J.; Reckermann, M. Introduction and Summary. In Second Assessment of Climate Change for the Baltic Sea Basin; The BACC II Author Team, Ed.; Springer Nature Switzerland: Cham, Switzerland, 2015.

69. Ministry of the Environment. Polish National Strategy for Adaptation to Climate Change (NAS 2020) with the Perspective by 2030; Ministry of the Environment: Warsaw, Poland, 2013.

70. Pacuk, M.; Palmowski, T.; Tarkowski, M. The Emergence of Baltic Europe: An Overview of Polish Research on Regional Integration. Quaest. Geogr. 2018, 37, 47-60. [CrossRef]

71. Otto, I.M.; Donges, J.F.; Cremades, R.; Bhowmik, A.; Hewitt, R.J.; Lucht, W.; Rockström, J.; Allerberger, F.; McCaffrey, M.; Doe, S.S.P.; et al. Social tipping dynamics for stabilizing Earth's climate by 2050. Proc. Natl. Acad. Sci. USA 2020, 117, 2354-2365. [CrossRef] [PubMed]

72. Hewitt, R.J.; Bradley, N.; Compagnucci, A.B.; Barlagne, C.; Ceglarz, A.; Cremades, R.; McKeen, M.; Otto, I.M.; Slee, B. Social innovation in community energy in Europe: A review of the evidence. Front. Energy Res. 2019, 7, 31. [CrossRef]

73. Chen, X.; Zhang, G. Study on the application of closed-loop lake water heat pump systems for lakefront buildings in south China climates. J. Renew. Sustain. Energy 2014, 6, 033125. [CrossRef]

74. Sewastianik, S.; Gajewski, A. Energetic and Ecologic Heat Pumps Evaluation in Poland. Energies 2020, 13, 4980. [CrossRef]

75. Ministerstwo Gospodarki Morskiej i Żeglugi Śródlądowej. Program Operacyjny EFMR (European Maritime and Fisheries FundOperational Programme for Poland, Revised 2018); Ministerstwo Gospodarki Morskiej i Żeglugi Śródlądowej: Warszawa, Poland, 2015.

76. Panciszko, B. Urban and Rural Local Action Groups in the Kuyavian-Pomeranian Voivodeship. Pol. Political Sci. Rev. 2020, 8 , 47-69. [CrossRef]

77. European Commission. Guidance for Member States and Programme Authorities on Community-led Local Development in European Structural and Investment Funds; European Commission: Brussels, Belgium, 2018.

78. Ministerstwo Infrastruktury i Rozwoju. Zasady realizacji instrumentu "Rozwój lokalny kierowany przez społeczność" w Polsce; Ministerstwo Infrastruktury i Rozwoju: Warszawa, Poland, 2014.

79. Neuendorf, K.A. The Content Analysis Guidebook, 2nd ed.; Sage Publications: Thousand Oaks, CA, USA; London, UK; New Delhi, India, 2002.

80. Babbie, E. The Basics of Social Research, 5th ed.; Wadsworth, Cengage Learning: Belmont, CA, USA, 2011.

81. Svobodová, H. Do the Czech Local Action Groups Respect the LEADER Method? Acta Univ. Agric. Et Silvic. Mendel. Brun. 2015, 63, 1769-1777. [CrossRef]

82. Hudečková, H.; Lošt'ák, M. The possibilities of measuring the efficiency of LEADER approach-Theoretical backgrounds and the outline of the methods. In Proceedings of the International Scientific Conference on Agrarian Perspectives XVIII-Strategies for the Future, Prague, Czech Republic, 15-16 September 2009; Svatoš, M., Lošt'ák, M., Zuzák, R., Eds.; Czech University of Life Sciences Pague, The Faculty of Economics and Management: Prague, Czech Republic, 2009; Volume 1, pp. 561-567.

83. Hotho, A.; Nürnberger, A.; Paaß, G. A brief survey of text mining. Zeitschrift für Computerlinguistik und Sprachtechnologie GLDV-Journal for Computational Linguistics and Language 2005, 20, $19-62$.

84. Krajewski, P.; Solecka, I. Management System of Urban Landscape in Poland on the Example of Wroclaw in the Context of European Landscape Convention Implementation. IOP Conf. Ser. Mater. Sci. Eng. 2019, 471, 112035. [CrossRef]

85. Sacchelli, S.; Fabbrizzi, S.; Menghini, S. Climate change effects and adaptation strategies in the wine sector: A quantitative literature review. Wine Econ. Policy 2016, 5, 114-126. [CrossRef]

86. Glinka, K. Place product in the promotion of communes-The case of the Milicz carp and the Barycz Valley. J. Educ. Cult. Soc. 2015, 6, 411-424. [CrossRef]

87. Świąder, M.; Tokarczyk-Dorociak, K.; Szewrański, S.; Kazak, J. Analiza zapisów regionalnych programów operacyjnych w latach 2014-2020 w kontekście finansowania inwestycji z zakresu OZE. Rynek Energii 2016, 3, 72-80.

88. Crawford, L.; Pollack, J. Hard and soft projects: A framework for analysis. Int. J. Proj. Manag. 2004, 22, 645-653. [CrossRef]

89. Futymski, A. Local Action Groups' Objectives (Conclusions drawn from the analysis of IRDS). LEADER+Q. 2007, 1, 6-9.

90. Kalisiak-Mędelska, M. Partnerstwo lokalne-Istota i znaczenie na przykładzie lokalnych grup działania. Bibl. Reg. 2013, 13, 73-96.

91. Piwowar, A.; Dzikuć, M. Development of Renewable Energy Sources in the Context of Threats Resulting from Low-Altitude Emissions in Rural Areas in Poland: A Review. Energies 2019, 12, 3558. [CrossRef]

92. Piepiora, Z.; Kachniarz, M.; Babczuk, A. The Efficiency of Low Water Retention in Polish Provinces—Spatial Analysis. In Hradec Economic Days, Double-Blind Peer-Reviewed Proceedings of the International Scientific Conference Hradec Economic Days 2017; Jedlička, P., Marešová, P., Soukal, I., Eds.; University of Hradec Králové: Hradec Králové, Czech Republic, 2017; Volume 7, pp. 689-695.

93. Navarro, F.A.; Cejudo, E.; Maroto, J.C. Participation of disadvantaged groups and governance in the LEADER and PRODER programmes in Andalucía, Spain. Stud. Agric. Econ. 2016, 118, 47-54. [CrossRef]

94. Thuesen, A.A.; Nielsen, N.C. A territorial perspective on EU's LEADER approach in Denmark: The added value of community-led local development of rural and coastal areas in a multi-level governance settings. Eur. Countrys. 2014, 6, 307-326. [CrossRef] 
95. Furmankiewicz, M. Współrządzenie czy ukryta dominacja sektora publicznego? Koncepcja governance w praktyce Lokalnych Grup Działania LEADER. Studia Reg. i Lokalne 2013, 1, 71-89.

96. Konečný, O.; Šilhan, Z.; Chaloupková, M.; Svobodová, H. Area-based approaches are losing the essence of local targeting: LEADER/CLLD in the Czech Republic. Eur. Plan. Stud. 2020, 29, 619-636. [CrossRef]

97. Servillo, L.; De Bruijn, M. From LEADER to CLLD: The Adoption of the New Fund Opportunities and of Their Local Development Options. Eur. Struct. Invest. Funds J. 2018, 6, 223-233.

98. Camacho, J.A.; Rodríguez, M.; Sánchez, L.M. Employment and Job Creation in the LEADER Approach. In Neoendogenous Development in European Rural Areas. Results and Lessons; Cejudo, E., Navarro, F., Eds.; Springer Nature: Cham, Switzerland, 2020; pp. 235-250.

99. European Environment Agency. Share of Renewable Energy in Gross Final Energy Consumption in Europe; European Environment Agency: Kobenhavn, Denmark. Available online: https://www.eea.europa.eu/data-and-maps/indicators/renewable-grossfinal-energy-consumption-5/assessment (accessed on 14 September 2021).

100. Van de Walle, G.; da Silva, S.G.; O’Hara, E.; Soto, P. Achieving Sustainable Development of Local Fishing Interests: The Case of Pays d'Auray FLAG. Sociol. Rural. 2015, 55, 360-377. [CrossRef]

101. De Boni, A.; Roma, R.; Palmisano, G.O. Fishery policy in the European Union: A multiple criteria approach for assessing sustainable management of Coastal Development Plans in Southern Italy. Ocean Coast. Manag. 2018, 163, 11-21. [CrossRef]

102. Rahmani, S.; Murayama, T.; Nishikizawa, S. Review of community renewable energy projects: The driving factors and their continuation in the upscaling process. IOP Conf. Ser. Earth Environ. Sci. 2020, 592, 012033. [CrossRef]

103. Azarova, V.; Cohen, J.; Friedl, C.; Reich, J. Designing local renewable energy communities to increase social acceptance: Evidence from a choice experiment in Austria, Germany, Italy, and Switzerland. Energy Policy 2019, 32, 1176-1183. [CrossRef]

104. Fouquet, D.; Johansson, T.B. European renewable energy policy at crossroads-Focus on electricity support mechanisms. Energy Policy 2008, 36, 4079-4092. [CrossRef]

105. Ptak, M. Public Support for Renewable Energy in Poland. Econ. Environ. Stud. 2017, 17, 707-724. [CrossRef]

106. Tanil, G.; Jurek, P. Policies on renewable energy at the European and national level of governance: Assessing policy adaptation in the Czech Republic. Energy Rep. 2020, 6, 548-553. [CrossRef]

107. Simionescu, M.; Strielkowski, W.; Tvaronavičiene, M. Renewable Energy in Final Energy Consumption and Income in the EU-28 Countries. Energies 2020, 13, 2280. [CrossRef]

108. Bak, I.; Spoz, A.; Zioło, M.; Dylewski, M. Dynamic Analysis of the Similarity of Objects in Research on the Use of Renewable Energy Resources in European Union Countries. Energies 2021, 14, 3952. [CrossRef]

109. Brodny, J.; Tutak, M.; Saki, S.A. Forecasting the Structure of Energy Production from Renewable Energy Sources and Biofuels in Poland. Energies 2020, 13, 2539. [CrossRef]

110. Brauers, H.; Oei, P.-Y. The political economy of coal in Poland: Drivers and barriers for a shift away from fossil fuels. Energy Policy 2020, 144, 111621. [CrossRef]

111. Dziaduszyński, K.; Tarka, M.; Trupkiewicz, M.; Szydłowski, K. Rozwój odnawialnych źródeł energii w sektorze Mikro, Małych i Średnich Przedsiębiorstw, w tym możliwość zastosowania rozwiąań prosumenckich. Stan obecny i perspektywy rozwoju; Ministerstwo Aktywów Państwowych: Warszawa, Poland, 2018.

112. Przybylska-Czastkiewicz, M. Prawne uwarunkowania rozwoju energetyki odnawialnej w Polsce po 2015 r. Polityka Energetyczna 2017, 20, 115-116.

113. Proszak-Miąsik, D.; Boryło, M. Wykorzystanie odnawialnych źródeł energii w małych gospodarstwach rolnych. Czas. Inżynierii Lądowej Środowiska i Archit. 2014, 61, 155-165.

114. Furmankiewicz, M.; Potocki, J.; Kazak, J. Land-Use Conflicts in the Sudetes, Poland. IOP Conf. Ser. Mater. Sci. Eng. 2019, 471, 092033.

115. Kazak, J.; van Hoof, J.; Szewrański, S. Challenges in the wind turbines location process in Central Europe-The use of spatial decision support systems. Renew. Sustain. Energy Rev. 2017, 76, 425-433. [CrossRef]

116. Skrzyńska, J. Raport z analizy badań świadomości, postaw i zachowań ekologicznych Polaków przeprowadzonych w Polsce w latach 2009-2015. Analiza TNS Polska dla Ministerstwa Środowiska; TNS Polska: Warszawa, Poland, 2015.

117. Wielewska, I. Rozwój OZE na obszarach wiejskich i ich wpływ na środowisko przyrodnicze w opinii doradców rolnych. Zesz. Nauk. Szkoły Głównej Gospod. Wiej. w Warszawie. Probl. Rol. Światowego 2014, 14, 186-195.

118. Gradziuk, P.; Gradziuk, B. Gospodarka niskoemisyjna-Nowe wyzwanie dla gmin wiejskich. Wieś i Rol. 2016, 1, 105-126. [CrossRef]

119. Woźniak, M. Zrównoważona gospodarka energetyczna na obszarach wiejskich w Polsce. Polityka Energetyczna 2018, $21,69-84$.

120. Standar, A.; Kozera, A.; Satoła, Ł. The Importance of Local Investments Co-Financed by the European Union in the Field of Renewable Energy Sources in Rural Areas of Poland. Energies 2021, 14, 450. [CrossRef]

121. Ropuszyńska-Surma, E.; Węglarz, M. Social acceptance of small-scale renewable energy in Lower Silesia in Poland. IOP Conf. Ser. Earth Environ. Sci. 2019, 214, 012037. [CrossRef]

122. Tirado-Ballesteros, J.G.; Hernández Hernández, M. Promoting tourism through the EU LEADER programme: Understanding Local Action Group governance. Eur. Plan. Stud. 2018, 27, 396-414. [CrossRef]

123. Sisto, R.; Lopolito, A.; Van Vliet, M. Stakeholder participation in planning rural development strategies: Using backcasting to support Local Action Groups in complying with CLLD requirements. Land Use Policy 2018, 70, 442-450. [CrossRef] 
124. Kyvelou, S.S.I.; Ierapetritis, D.G. Fisheries Sustainability through Soft Multi-Use Maritime Spatial Planning and Local Development Co-Management: Potentials and Challenges in Greece. Sustainability 2020, 12, 2026. [CrossRef]

125. Novikova, M.; de Fátima Ferreiro, M.; Stryjakiewicz, T. Local development initiatives as promoters of social innovation: Evidence from two European rural regions. Quaest. Geogr. 2020, 39, 43-53. [CrossRef]

126. Hoffmann, R.; Hoffmann, N. The LEADER Programme as an Impulse for New Projects in Rural Areas. Quaest. Geogr. 2018, 37, 141-150.

127. Kola-Bezka, M. Are LAGs contributing to solving social exclusion problems? The case of Kujawsko-Pomorskie Voivodship. Bull. Geogr. Socio-Econ. Ser. 2020, 48, 35-45. [CrossRef]

128. Galindo-Pérez-de-Azpillaga, L.; Foronda-Robles, C. Digital governance and information technologies in local action groups (LAGs). Cogent Soc. Sci. 2018, 4, 1528730. [CrossRef]

129. Janc, K.; Czapiewski, K.; Wójcik, M. In the starting blocks for smart agriculture: The internet as a source of knowledge in transitional agriculture. NJAS-Wagening. J. Life Sci. 2019, 91-92, 100309. [CrossRef]

130. Macken-Walsh, Á. Operationalising Contemporary Rural Development: Socio-Cultural Determinants Arising from a Strong Local Fishing Culture. Hum. Ecol. 2012, 40, 199-211. [CrossRef]

131. Bedrac, M.; Cunder, T. "Leader" approach and local development strategies in Slovenia. In Linking Competitiveness with Equity and Sustainability: New Ideas for the Socio-Economic Development of Rural Areas; Fieldsend, A., Ed.; European Rural Development Network: Warszawa, Poland, 2010; pp. 245-256.

132. Doitchinova, J.; Miteva, A.; Stoyanova, Z. The process of creating local action groups in Bulgaria-Problems and prospects. Sci. Ann. "Alexandru Ioan Cuza" Univ. Iaşi. Econ. Sci. 2012, 59, 183-208. [CrossRef]

133. European Leader Association for Rural Development. Analysis of ELARD Members Questionnaire; European Leader Association for Rural Development: Brussels, Belgium, 2016.

134. Rogers, J.C.; Simmons, E.A.; Convery, I.; Weatherall, A. Public perception of opportunities for community-based renewable energy projects. Energy Policy 2008, 36, 4217-4226. [CrossRef]

135. Krug, M.; Di Nucci, M.R. Citizens at the heart of the energy transition in Europe? Opportunities and challenges for community wind farms in six European countries. Renew. Energy Law Policy Rev. 2020, 9, 9-27. 